\title{
Identifikasi tungau hama pada tanaman pepaya di Pulau Lombok
}

\author{
Identification of pest mite on papaya in the Lombok Island
}

\author{
Wieke Mei Dina, Sugeng Santoso* \\ Departemen Proteksi Tanaman, Fakultas Pertanian, Institut Pertanian Bogor \\ Jalan Kamper Kampus IPB Dramaga, Bogor 16680
}

(diterima Januari 2017, disetujui Maret 2017)

\begin{abstract}
ABSTRAK
Pulau Lombok (Nusa Tenggara Barat) merupakan salah satu penghasil pepaya terbesar di Indonesia. Produksi pepaya di Pulau Lombok terus menurun pada lima tahun terakhir. Tungau hama merupakan salah satu penyebab penurunan produksi pepaya di Indonesia. Belum tersedia data tentang tungau hama pada tanaman pepaya di Pulau Lombok sampai saat ini. Oleh karena itu, penelitian ini bertujuan untuk menentukan spesies tungau hama pepaya di Pulau Lombok. Tungau dikumpulkan dari 50 lokasi pertanaman pepaya yang tersebar di 4 kabupaten dan 1 kota di Pulau Lombok secara purposive sampling, masing-masing 2 daun dari 3 tanaman, yaitu daun yang bergejala serangan tungau. Identifikasi morfologi tungau dilakukan berdasarkan karakter stigma dan chaetotaksi pada gnathosoma dan idiosoma. Terdapat dua belas spesies tungau hama yang ditemukan, yaitu Aculops pelekassi Keifer dan Calacarus carinatus Keifer dari famili Eriophyidae; Brevipalpus californicus Banks, B. obovatus Dannadieu, B. phoenicis Geijskes, dan Tenuipalpus pasificus Baker dari famili Tenuipalpidae; Eutetranychus africanus Tucker, Panonychus citri McGregor, Tetranychus fijiensis Hirst, T. kanzawai Kishida, dan T. piercei McGregor dari famili Tetranychidae dan Tarsonemus bilobatus Suski dari famili Tarsonemidae.
\end{abstract}

Kata kunci: chaetotaksi, Eriophyidae, identifikasi, Tenuipalpidae, Tetranychidae

\begin{abstract}
Lombok Island (West Nusa Tenggara) is one of the major papaya producer in Indonesia. In the last five years, papaya production in West Nusa Tenggara has decrease continuosly. Pest mites is one the constraint found in papaya production in Indonesia. At the present there is no data available related with mites on papaya in Lombok island. Thus, the aim of the research is to determine the identity of pest mites on papaya in Lombok Island. Mites collected from 50 different location of 5 districts in Lombok Island. From each location, 3 plant were sampled for observation, two leaves from each plants were collected. Identification of mites were conducted by using morphological characters such as stigma, gnathosoma, and idiosoma. The results revealed twelve spesies of pest mites of papaya in Lombok island, they were Aculops pelekassi Keifer, Calacarus carinatus Keifer, Brevipalpus californicus Banks, B. obovatus Dannadieu, B. phoenicis Geijskes, Tenuipalpus pasificus Baker, Eutetranychus africanus Tucker, Panonychus citri McGregor, Tetranychus fijiensis Hirst, T. kanzawai Kishida, T. piercei McGregor, and Tarsonemus bilobatus Suski.
\end{abstract}

Key words: Eriophyidae, identification, morphology, Tenuipalpidae, Tetranychidae

\section{PENDAHULUAN}

Propinsi Nusa Tenggara Barat merupakan salah satu propinsi dengan produksi pepaya yang tinggi pada tahun 2010-2015, yaitu mencapai 24.26911.311 ton. Produksi pepaya tahun 2015 jauh lebih rendah dibandingkan dengan yang dicapai tahun 2010 (BPS 2014). Salah satu penyebab

\footnotetext{
*Penulis korespondensi: Sugeng Santoso. Departemen Proteksi Tanaman, Fakultas Pertanian, Institut Pertanian Bogor,

Jalan Kamper, Kampus IPB Darmaga Bogor 16680, Tel: 0251-8629364, Faks: 0251-8629362, Email: soe3toso@yahoo.com.
} 
penurunan produksi pepaya diduga karena adanya serangan hama dan penyakit tanaman. Salah satu penyakit penting pada tanaman pepaya di Pulau Lombok adalah Papaya ringspot virus (PRSV) dan hama pentingnya adalah Paracoccus marginatus Williams \& Granara de Willink dan beberapa jenis tungau hama. Menurut AbatoZarate et al. (2014), penurunan produksi pepaya di Meksiko salah satunya disebabkan oleh serangan tungau, diantaranya adalah Eutetranychus banksi (McGregor), Eotetranychus lewisi (McGregor), Polyphagotarsonemus latus Banks, Tetranychus urticae Koch CL, Tetranychus merganser Boudreaux, dan Calacarus citrifolii Keifer. Tungau hama dapat menyerang pepaya sepanjang tahun dan memerlukan pengendalian menggunakan pestisida secara terus menerus sehingga dapat meningkatkan biaya pengendalian. Serangan Tetranychus kanzawai Kishida pada stroberi di Taiwan menimbulkan biaya pengendalian hingga \$233/ha (Chang \& Huang 1995).

Identifikasi morfologi tungau berdasarkan karakteristik stigma dan chaetotaksi atau pola sebaran dan jumlah seta pada gnathosoma dan idiosoma, memerlukan referensi dan kemampuan taksonomi yang memadai karena beberapa spesies memiliki ciri morfologi yang hampir sama yang sulit dibedakan. Genus Oligonychus dan Tetranychus memiliki karakter khusus aedeagus jantan dewasa (Zhang 2003).

Data spesies dan keanekaragaman spesies tungau hama pada tanaman pepaya di Pulau Lombok belum tersedia sehingga perlu dilakukan identifikasi spesies. Penelitian ini bertujuan untuk menentukan spesies tungau hama pada tanaman pepaya di Pulau Lombok.

\section{BAHAN DAN METODE}

Pengambilan sampel dilakukan pada 50 lokasi pertanaman pepaya di Pulau Lombok yang tersebar di Kabupaten Lombok Barat, Lombok Timur, Lombok Tengah, Lombok Utara dan Kota Mataram secara purposive sampling pada 3 tanaman pepaya bergejala serangan tungau, masing-masing 2 daun, terdiri atas 1 daun muda dan 1 daun tua/sedang. Identifikasi morfologi tungau berdasarkan karakteristik stigma dan chaetotaksi di Laboratorium Karantina Tumbuhan, Balai Karantina Pertanian Kelas I Mataram pada Bulan Juli-Desember 2016.

\section{Penanganan dan preservasi tungau}

Sampel daun pepaya sampel digenangi alkohol $70 \%$ dan ditutup hingga tungau mati (Zhang 2003). Larutan disaring dengan sieve 850, 105, dan $20 \mu \mathrm{m}$, hasilnya disimpan dalam ethanol $70 \%$ dan diberi label. Tungau dikelompokkan dan dihitung berdasarkan kemiripan morfologi.

\section{Identifikasi morfologi tungau dan pembuatan kunci determinasi}

Identifikasi morfologi tungau berdasarkan karakteristik chaetotaksi diawali proses clearing tungau betina dan jantan, yaitu tungau diletakkan pada gelas objek yang telah ditetesi media Hoyer's dan dipanaskan pada suhu $60{ }^{\circ} \mathrm{C}$ selama $1 \mathrm{jam}$, kemudian diidentifikasi. Identifikasi tungau menggunakan mikroskop compound (Nikon eclipse 400) dan berdasarkan laporan ilmiah terkait (Keifer et al. 1982; Zhang 2003; Vacante 2010; Seeman \& Beard 2011; Naing et al. 2014). Proses pembuatan kunci identifikasi dengan melihat karakter chaetotaksi setiap spesies, kemudian membuat tabel persamaan dan perbedaan karakter, mengelompokkan atau memisahkan spesies satu dengan yang lainnya untuk menyusun kunci identifikasi dikotomi.

\section{HASIL}

Terdapat 12 spesies tungau hama yang ditemukan pada tanaman pepaya di Pulau Lombok terdiri atas 4 marga, yaitu Eriophyidae, Tarsonimidae, Tenuipalpidae, dan Tetranychidae. Tungau hama pepaya yang ditemukan adalah Aculops pelekassi Keifer, Calacarus carinatus Keifer, Tarsonemus bilobatus Suski., Brevipalpus californicus Banks, B. obovatus Dannadieu, B. phoenicis Geijskes, Tenuipalpus pasificus Baker, Eutetranychus africanus Tucker, Panonychus citri McGregor, Tetranychus fijiensis Hirst, T. kanzawai Kishida, dan T. piercei McGregor (Gambar 1). 

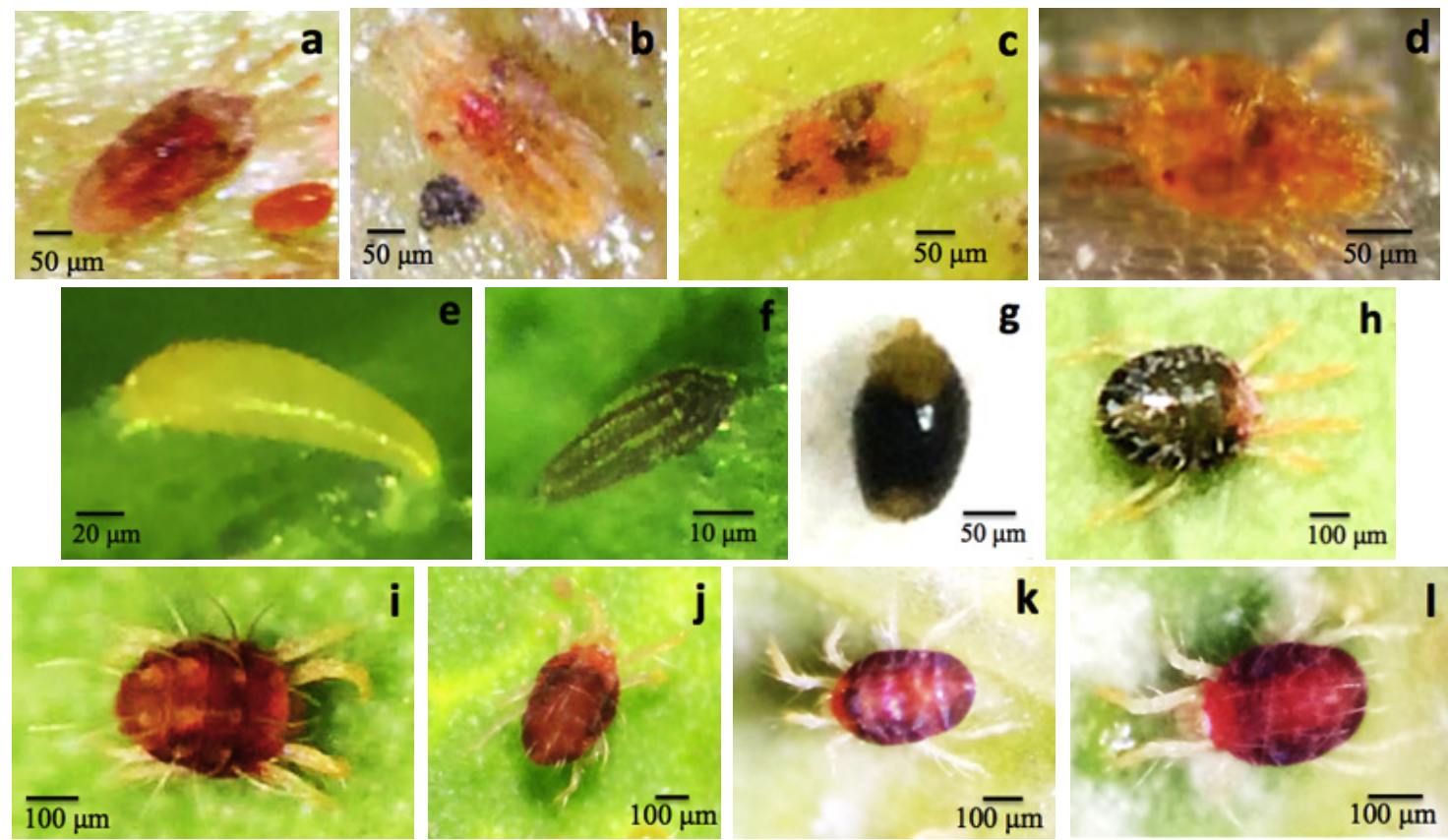

Gambar 1. Tungau segar. a: Brevipalpus californicus; b: B. obovatus; c: B. phoenicis; d: Tenuipalpus pasificus; e: Aculops pelekassi; f: Calacarus carinatus; g: Tarsonemus bilobatus; h: Eutetranychus africanus; i: Panonychus citri; j: Tetranychus fijiensis; k: T. kanzawai; 1: T. piercei.

\section{Kunci determinasi tungau hama pada pepaya di Pulau Lombok}

1a. Tubuh beranulasi, berbentuk fusiform dengan 2 pasang (ps) tungkai (Eriophyidae) ....................5

1b. Tubuh tidak beranulasi, berbentuk bulat atau oval dengan $4 \mathrm{ps}$ tungkai ......................................

2a. Stigmata pada anterolateral propodosoma, segmen hysterosoma sangat jelas ................................

2b. Stigmata terdapat pada pangkal selisera, hysterosoma tanpa segmen .............................................

3a. Tungkai IV dengan 3-4 segmen, femur, dan genu menyatu (Tarsonemidae) .............................. 8

3b. Tungkai IV dengan 5 segmen, femur, dan genu terpisah (Siteroptidae)

4a. Palpus tanpa cakar, memiliki sejugal furrow, dorsoventral pipih (Tenuipalpidae) .12

4b. Palpus memiliki cakar, tanpa sejugal furrow, dorsoventral bulat (Tetranychidae)

5a. Tubuh vermiform, annuli dorsoventral hampir sama, bagian depan 1/2 atau 2/3 dari opistosoma; bagian prodorsal tanpa frontal lobe, jika memiliki frontal lobe sangat tipis, dan menyatu dengan annuli yang tipis (Eriophyinae)

5b. Tubuh fusiform; bagian prodorsal dengan pangkal yang lebar, memiliki frontal lobe hingga gnathosoma; opistosoma dorsal annuli lebih lebar dibanding annuli ventral (Phyllocoptinae) .....6

6a. Tanpa seta scapular ( $s c$ ); tanpa atau dengan tuberkel scapular (Calacarini); dorsum dengan 3 ridges tengah dan ridges lateral; opistosoma meruncing pada bagian belakang, memiliki seta tibia (Calacarus); memiliki 5 garis tergal lateral putih, seperti lilin (Gambar 2a); pada opisthoma terbentuk 4 alur longitudinal (Gambar 2b); prodorsal memiliki pola garis melintang/ anulasi; 5 rumbai empodial feather claw pada tungkai (Gambar 2c) dan 2 seta pada tibia I dan 1 seta pada tibia II (Gambar 2d); tergit (annuli dorsal) pada opistosoma lebih lebar dan sedikit daripada annuli ventral (sternites); annuli ventral mikrotuberkel, tidak memiliki seta h1

Calacarus carinatus Keifer (Keifer et al.1982)

6b. Memiliki scapular seta (sc) dan tuberkel dekat bagian tepi, mengarah ke belakang; tuberkel scapular subcylindrical (Anthocoptini).

7a. Lempeng prodorsal depan menajam, tanpa duri; tubuh fusiform dan pipih; empodium tersusun dari 4-5 bulu. (Aculops); berwarna kuning dan panjang 170-200 $\mu \mathrm{m}$ prodorsal memiliki pola menyerupai jaring (Gambar 2e); seta proximal di coxisternum III (3a) dan seta $d$ panjang; annuli 
dorsal 42-45, annuli ventral 50-55 (Gambar 2g); empodia 4 rumbai, sebagian bercabang (Gambar 2f); tungkai I-II, 6 ruas; tarsus dengan 1 claw bercabang.. Aculops pelekassi Keifer (Lee et al. 2014)

7b. Lempeng prodorsal dengan frontal lobe lebar dan membulat, tidak menajam; memiliki 2 atau 4 duri kecil di bagian tepi bawah mengarah ke depan (Aculus)

8a. Bagian ventral metapodosomal memiliki 4 ps seta; tungkai IV jantan memiliki bantalan, seperti cakar (Polyphagotarsonemus)

8b. Metapodosomal ventral dengan 2 ps seta; tungkai IV jantan memiliki cakar

9a. Panjang tegula kurang dari 1,5 kali lebar pangkalnya, dengan tepi membulat; lebar gnathosoma lebih dari panjangnya; stigmata dekat seta $v$ (Steneotarsonemus)

9b. Panjang tegula kurang dari 1,5 kali lebar pangkalnya; panjang gnathosoma lebih dari lebarnya; stigmata tidak dekat seta $v$

10a. Pangkal apodema 4 sampai pada pangkal seta posterolateral 3b (Phytonemus)

10b. Pangkal apodema 4 tidak sampai pangkal seta posterolateral 3b (Gambar 2h) (Tharsonemus) ......6

11a. Apodeme sejugal membulat

Tarsonemus floricolus

11b. Apodeme sejugal terbelah di tengah (Gambar 2i) ............Tarsonemus bilobatus Suski (Zhang 2003)

12a. Hysterosoma cekung; opistosoma menyempit (Gambar 2j) (Tenuipalpus); memiliki 1 ps seta posterolateral lebih panjang (Flagella) dibandingkan 4 ps seta lainnya (e3,f3,f2,h1) (Gambar 2k); memiliki 2 ps seta genital; palpus 3 segmen, palpus segmen ketiga pendek dengan 1 seta pendek dan 1 seta melengkung panjang ................................ Tenuipalpus pacificus Baker (Zhang 2003)

12b. Hysterosoma cembung; opistosoma tidak menyempit; seta posterolateral memiliki panjang yang sama (Brevipalpus)

13a. Tarsus II memiliki 1 solenidia (Gambar 21); pola median prodorsum memudar; hysterosoma dengan 6 pasang seta dorsolateral (c3, d3, e3, f3, h2, dan h1); tidak memiliki f2 (Gambar 2m)

Brevipalpus obovatus Dannadieu (Welbourne et al. 2003)

13b. Tarsus II memiliki 2 solenidia (Gambar 2n dan 2p); pola scallop di median prodorsum .............14

14a. Hysterosoma dengan 7 ps seta dorsolateral (c3, d3, e3, f3,f2, h2 dan h1); memiliki f2 (Gambar 2o) ..

Brevipalpus californicus Banks (Welbourne et al. 2003)

14b. Hysterosoma dengan 6 ps seta dorsolateral ((c3, d3, e3, f3,f2, h2 dan h1); tidak memiliki f2 (Gambar 2q). Brevipalpus phoenicis Geijskes (Welbourne et al. 2003)

15a. Empodium memiliki cakar; tarsus I dengan 1 ps seta dupleks, seta terpisah (Eurytetranychini) ..16

15b. Empodium dengan bagian, seperti cakar; tarsus I dengan 2 ps seta dupleks dan 1 ps pada tarsus II; opistosoma dengan $f_{1}$ di dorsal (Tetranychini).

16a. Memiliki 2 ps seta pseudanal $\left(p s_{1-2}\right) ; 13$ ps seta idiosomal lanceolate hingga subspatulate pada bagian dorsal (Gambar 2r) (Eutetranychus).

16b. Memiliki 1 ps seta pseudanal; 10 ps seta dorsal opistosomal (Aponychus)

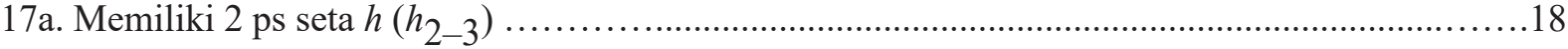

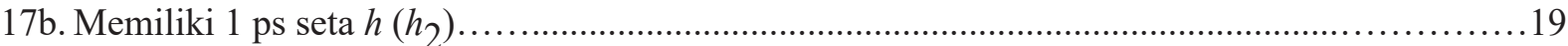

18a. Seta pada tubuh tidak berpangkal pada tuberkel yang menonjol; empodium tanpa cakar dengan 3 pasang rambut proximoventral (Eotetranychus)

18b. Seta tubuh berpangkal pada tuberkel menonjol (Gambar 2t); empodium, seperti cakar dengan 3 ps rambut proximoventral (Gambar $2 \mathrm{u}$ ) (Panonychus).

19a. Empodium menyerupai cakar, lebih pendek atau sama panjang dengan rambut proximoventral; peritreme lurus dengan ujung sedikit membulat; tarsus I memiliki seta dupleks terpisah(Oligonychus)

19b. Empodium dengan 3 ps rambut proximoventral; peritreme menyiku (Gambar 2w), tarsus I dengan seta dupleks berdekatan (Tetranychus)

20a. Memiliki 4 ps seta dorsocentral $\left(f_{1}\right)$; seta tactile (I-IV): koksa 2-2-1-1, femur 8-6-3-1, genu 5-5-22, tibia 9-6-6-7, 1 seta pada koksa II

Eutetranychus orientalis (Klein) 
20b. Memiliki 4 ps seta dorsocentral $\left(f_{1}\right)$; panjang seta dorsocentral $\mathrm{c} 1$, d1, e1, dan f1 setengah dari panjang setadorsolateral c2, d2, e2, danf2; seta tactile(I-IV): koksa2-2-1-1, femur 8-6-3-1, genu 5-5-22, tibia 9-6-6-7, 2 seta pada koksa II (Gambar2s) ...Eutetranychus africanus Tucker (Naing et al. 2014) 21a. Memiliki 8 seta pada femur I; 1 solenidia pada tibia I; hysterosoma memiliki panjang seta clunal (h1) yang sama dengan seta outer sacral (f2); f2 hampir 1/3 dari panjang seta inner sacral (f1) (Gambar 2v)

Panonychus citri McGregor (Zhang 2003)

21b. Memiliki 8 seta pada femur I; 1 solenidia pada tibia I; hysterosoma memiliki panjang seta clunal (h1) 2/3 dari panjang seta outer sacral (f2); f2 lebih dari $1 / 2$ atau hampir sama panjang seta inner sacral (f1)

Panonychus ulmi Koch

22a. Empodia betina dengan 2 ps rambut proximoventral; bagian dorsal lebih kecil dibandingkan dengan ventral; memiliki empodial spur (rambut, seperti cakar); aedeagus jantan panjang, ujung meruncing (Gambar 2x)....

Tetranychus fijiensis Hirst (Seeman \& Beard 2011).

22b. Empodia betina dengan 3 ps rambut proximoventral; tanpa atau dengan empodial spur; aedeagus jantan memiliki apical knob; jika tidak memiliki knob, biasanya aedeagus tidak terlalu panjang ..23

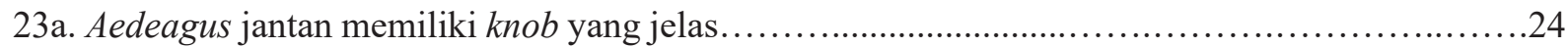

23b. Aedeagus jantan tanpa knob, sedikit sigmoid dengan leher aedagus meruncing hingga ujungnya (Gambar 2y)

Tetranychus piercei McGregor (Seeman \& Beard 2011)

24a. Knob pada aedeagus besar, sekitar 2 kali lebar leher aedagus; bagian tepi dorsal knob menyudut, ujungnya sedikit membulat (Gambar 2z) .... Tetranychus kanzawai Kishida (Seeman \& Beard 2011)

24b. Knob pada aedeagus kecil, kurang dari 2 kali (sekitar 1,5 kali) lebar leher aedagus; bagian tepi dorsal knob menyudut dan ujung membulat

Tetranychus urticae Koch

\section{PEMBAHASAN}

Beberapa spesies dari 12 spesies tungau hama yang ditemukan pada tanaman pepaya di Pulau Lombok telah dilaporkan merupakan hama penting pada tanaman jeruk, diantaranya adalah A. pelekassi, B. californicus, B. phoenicis, B. obovatus, E. africanus, dan P. citri. T. fijiensis diketahui sebagai hama kelapa dan palem, tetapi juga sebagai hama minor pada tanaman jeruk. Tungau-tungau hama tersebut diketahui selain menyerang jeruk juga menyerang tanaman lainnya termasuk pepaya. Spesies tungau hama yang diketahui merupakan hama penting pada pepaya diantaranya adalah T. piercei, B. phoenicis, P. citri, dan E. africanus. C. carinatus dan T. kanzawai diketahui merupakan hama utama pada teh, sedangkan T. pasificus dan T. bilobatus diketahui sebagai hama pada tanaman hias. Hasil penelitian menyatakan bahwa selain menjadi hama penting pada jeruk, kelapa dan teh, spesies-spesies tungau hama tersebut dapat menjadi hama penting pada tanaman pepaya, terutama spesies yang sering ditemukan dalam jumlah banyak di beberapa lokasi pengambilan sampel berbeda.
Jumlah total 30.205 individu terdiri atas 12 spesies tungau hama ditemukan pada tanaman pepaya varietas Callina (California Indonesia), Thailand dan lokal dari 50 lokasi pertanaman pepaya di Pulau Lombok. Jumlah individu tertinggi tungau hama yang ditemukan pada tanaman pepaya di Pulau Lombok adalah spesies P. citri, yaitu 7.157 individu dan terendah adalah spesies T. pasificus, yaitu 3 individu. Spesies tungau hama dominan yang ditemukan pada daun pepaya sampel adalah $P$. citri, E. africanus, $T$. piercei, dan B. californicus. Tingginya populasi spesies tungau hama dominan disebabkan kesesuaian suhu optimum untuk pertumbuhan dan perkembangbiakan tungau. Lingkungan budi daya dan lingkungan alami di Pulau Lombok sangat mendukung untuk perkembangan tungau hama tersebut. Suhu rata-rata di Pulau Lombok pada bulan Juli-Agustus 2016 berkisar antara 18,4$35,1{ }^{\circ} \mathrm{C}$ dan kelembaban relatif 71-88\% (BMKG 2016). Suhu optimum untuk perkembangan $B$. californicus $16-23{ }^{\circ} \mathrm{C}$ dan kelembaban relatif 65 $95 \%$, B. californicus dapat mempercepat siklus hidupnya pada suhu $27{ }^{\circ} \mathrm{C}$ sehingga lebih cepat dewasa dan meletakkan telur (Vacante 2010). 


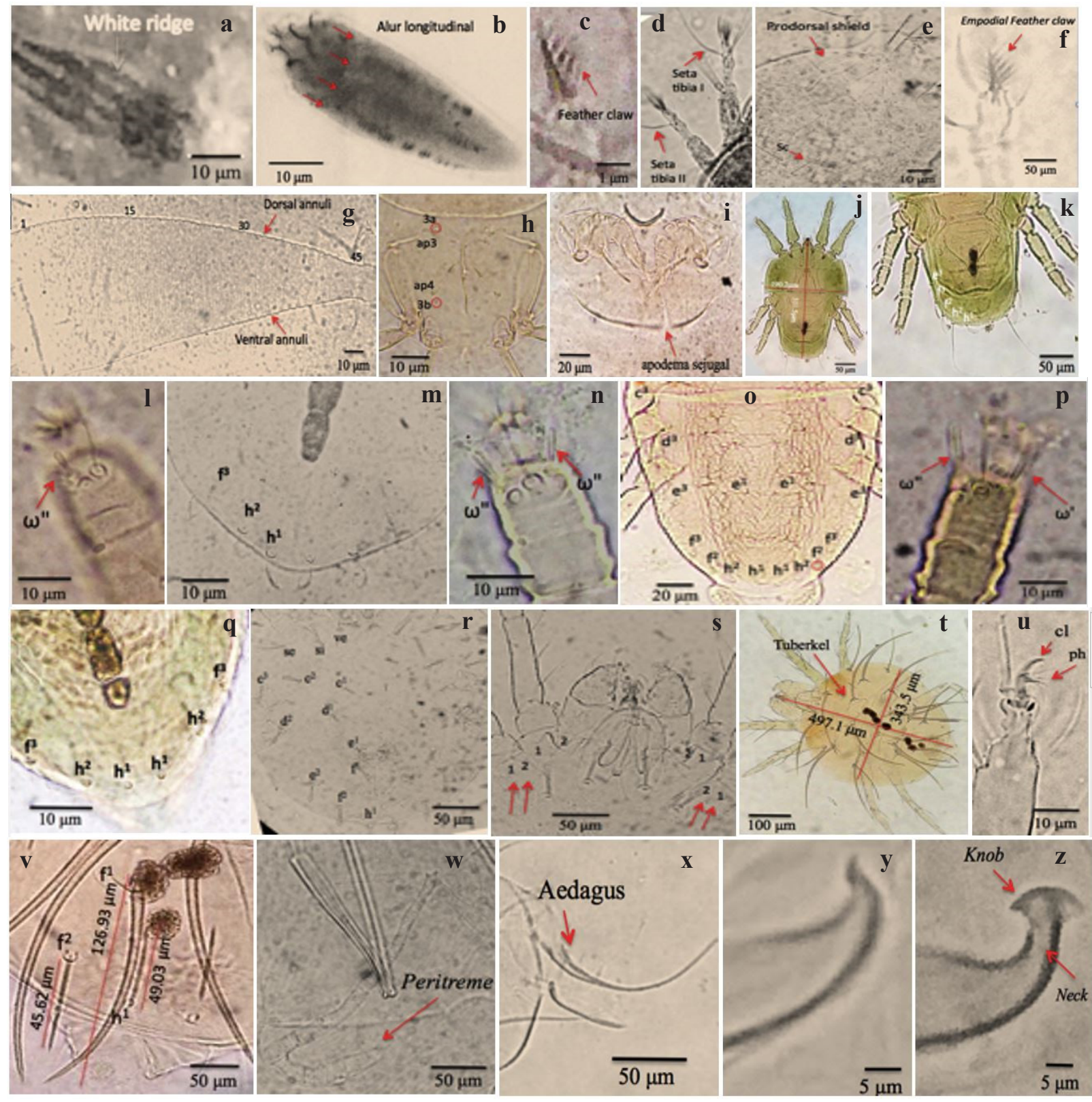

Gambar 2. Karakter morfologi. a: dorsal Calacarus carinatus; b: opitosoma C. carinatus; c: tarsus $C$. carinatus; d: tibia I dan II C. carinatus; e: prodorsal Aculops pelekassi; f: tarsus A. pelekassi; g: dorsal annuli A. pelekassi; h: apodema posternal (ap) Tarsonemus bilobatus; i: apodema sejugal T. bilobatus; j: dorsal Tenuipalpus pasificus; k: hysterosoma T. pasificus; 1: tarsus II Brevipalpus obovatus; m: hysterosoma B. obovatus; n: tarsus II B. californicus; o: hysterosoma B. californicus; p: tarsus II B. phoenicis; q: hysterosoma B. phoenicis; r: opistosoma Eutetranychus africanus; s: koksa II E. africanus; t: dorsal Panonychus citri; u: tarsus P. citri; v: seta f1 dan f2 P. citri; w: peritreme Tetranychus fijiensis; $\mathrm{x}$ : aedagus $T$. fijiensis; y: aedagus T. piercei; z: aedagus T. kanzawai.

Suhu optimum untuk perkembangan $P$. citri dan $E$. africanus adalah $25-30{ }^{\circ} \mathrm{C}$ (Vacante 2010).

Persebaran tungau hama yang ditemukan pada tanaman pepaya di Pulau Lombok berdasarkan umur daun adalah sejumlah 5.159 individu pada daun muda dan 25.046 individu pada daun tua atau sedang. Daun tua atau sedang lebih disukai tungau karena posisi daun terlindung dari panas sinar 42 matahari langsung dibandingkan dengan daun muda, selain itu daun tua lebih lebar sehingga populasi tungau yang ditemukan lebih tinggi dibandingkan dengan daun muda. Spesies tungau hama yang ditemukan pada daun tua maupun muda hampir sama, kecuali T. pasificus hanya ditemukan pada daun tua, sedangkan A. pelekassi dan T. bilobatus lebih banyak ditemukan pada daun 
muda dibandingkan dengan daun tua. Menurut Vacante (2010) A. pelekassi sulit dibedakan dengan Phyllocoptruta oleivora (Ashmead), tetapi A. pelekassi lebih menyukai daun muda yang terkena sinar matahari langsung terutama pada bagian tepi daun, sedangkan $P$. oleivora lebih menyukai daun tua yang terlindung dari sinar matahari langsung.

Keragaman spesies tungau hama pada tanaman pepaya di Pulau Lombok termasuk tinggi, tidak ada spesies yang dominan atau tidak ada penguasaan suatu spesies terhadap spesies tungau lainnya dan sebarannya merata. Dominansi spesies yang rendah menunjukkan bahwa jumlah individu tiap-tiap spesies relatif sama dan menyebar merata. Dominansi rendah dan kemerataan yang tinggi dalam persebaran spesies tungau hama menunjukkan kemampuan masingmasing spesies untuk mempertahankan populasi dan keanekaragaman spesiesnya (Oka 1995).

Keragaman spesies tungau hama yang rendah berpotensi menimbulkan ledakan tungau spesies tertentu terutama spesies yang dominan. Salah satu tindakan untuk mencegah terjadinya ledakan tungau hama adalah dengan menjaga keragaman spesies tungau hama tetap tinggi sehingga mencegah adanya dominansi spesies tungau hama tertentu. Populasi tungau hama dominan dapat meningkat cepat apabila terdapat tanaman pepaya dalam jumlah banyak atau tersedia inang lainnya sehingga menimbulkan kerusakan dan kerugian ekonomi terhadap pertanian. Tungau hama dapat memanfaatkan tanaman pepaya yang ada untuk berkembang dan meningkatkan populasinya, kemudian menyebar ke tanaman lain di sekitarnya.

\section{KESIMPULAN}

Duabelas spesies tungau hama yang ditemukan pada tanaman pepaya di Pulau Lombok, yaitu A. pelekassi, B. californicus, B. phoenicis, B. obovatus, T. pasificus, C. carinatus, E. africanus, P. citri, T. piercei, T. fijiensis, T. kanzawai, dan T. bilobatus.

\section{UCAPAN TERIMA KASIH}

Terima kasih kepada Badan Karantina Pertanian, Kementerian Pertanian Republik Indonesia yang telah mendanai penelitian ini.

\section{DAFTAR PUSTAKA}

Abato-Zarate M, Villanueva-jimenez J, Otero-colina G, Avila-Resendiz C, Hernandez-Castro E, Reyes-perez N. 2014. Acarofauna associated to papaya orchards in Veracruz, Mexico. Acta Zoologica Mexicana 30:595-609.

[BPS] Badan Pusat Statistik. 2014. Produksi pepaya Indonesia. Available at: https://www.bps.go.id/. [accessed 11 Maret 2016].

[BMKG] Badan Metereologi, Klimatologi dan Geofisika. 2016. Buletin Iklim Provinsi Nusa Tenggara Barat Edisi September 2016.Available at: http://iklim.ntb.bmkg.go.id/. [accessed 15 November 2016].

Chang CP, Huang SC. 1995. Evaluation of effectiveness of releasing green lacewing Mallada basalis (Walker) for the control of tetranychid mites on strawberry. Plant Protection Bulletin 37:41-58.

Keifer HH, Baker EW, Kono T, Delfinado M, Styer WE. 1982. An Illustrated Guide to Plant Abnormalities Caused by Eriophyid Mites in North America. Washington: US Government Printing Office.

Lee J, Sunghoon J, Lee S. 2014. Taxonomic review of the Tribe Anthocoptini (Acari: Eriophyidae) from Korea. Journal of Asia-Pacific Entomology 17:383-394. doi: https://doi.org/10.1016/j. aspen.2013.10.008.

Naing HH, Chandrapatya A, Navajas M, Auger P. 2014. Know more about spider mites (Acari: Tetranychidae) in Myanmar. Zootaxa 3802:257275. doi: https://doi.org/10.11646/zootaxa.3802.2.7.

Oka IN. 1995. Pengendalian Hama Terpadu dan Implementasinya di Indonesia. Yogyakarta: Gadjah Mada University.

Seeman OD, Beard JJ. 2011. Identification of exotic pest and Australian native and naturalised species of Tetranychus (Acari: Tetranychidae). Zootaxa 2961:1-72.

Vacante V. 2010. Citrus Mite: Identification, Bionomy and Control. Wallingford: CABI Publishing.

Welbourne WC, Ochoa R, Kane EC, Erbe EF. 2003. Morphological observations on Brevipalpus phoenicis (Acari: Tenuipalpidae) including comparisons with $B$. californicus and $B$. obovatus. Experimental and Applied Acarology 30:107-133. doi: https://doi.org/10.1023/ B:APPA.0000006545.40017.a0.

Zhang ZQ. 2003. Mites of Greenhouses, Identification, BiologyandControl.Wallingford:CABIPublishing. doi: https://doi.org/10.1079/9780851995908.0000. 